\title{
Transition metal-catalyzed reactions of $N$-sulfinyl imines
}

\author{
Francisco Foubelo $^{\mathrm{a}, \mathrm{b}}$, Carmen Nájera ${ }^{\mathrm{b}}$, José M. Sansano ${ }^{\mathrm{a}, \mathrm{b}}$, Miguel Yus ${ }^{\mathrm{b}, *}$ \\ a Departamento de Química Orgánica and Instituto de Síntesis Orgánica (ISO), Universidad de Alicante, Apdo. 99, 03080 Alicante, Spain \\ ${ }^{\mathrm{b}}$ Centro de Innovación en Química Avanzada (ORFEO-CINQA), Universidad de Alicante, Apdo. 99, 03080 Alicante, Spain
}

\section{A R T I C L E I N F O}

\section{Article history:}

Received 25 February 2021

Revised 6 April 2021

Accepted 13 April 2021

Available online 20 April 2021

\section{Keywords:}

Chiral sulfinyl imines

Transition metals

Addition reactions

Hydrogenations

Transfer hydrogenations

\begin{abstract}
A B S T R A C T
Transition metal-catalyzed reactions of $N$-sulfinyl imines with several substrates lead to the corresponding chiral amines with high yields and diastereo- or enantioselectivities. As metals, titanium, copper, ruthenium, rhodium, palladium and silver have been successfully used as catalysts in different carbon-carbon forming reactions as well as hydrogenations with molecular hydrogen or transfer hydrogenations with isopropanol as hydrogen source.
\end{abstract}

(c) 2021 Elsevier Ltd. All rights reserved.

\section{Introduction}

Chiral $\mathrm{N}$-sulfinyl imines are important starting materials in asymmetric synthesis because in the reaction with carbon nucleophiles a new carbon-carbon bond is formed and a new stereocenter is generated [1]. As nucleophiles mainly organometallic reagents have been used, such as organoalkaline, organomagnesium, organozinc, organoboron, organoaluminium, organoindium and organosilicon compounds [2]. In our group we have been investigating the indium-promoted allylation of chiral $N$-sulfinyl imines [3] and its application to the synthesis of several chiral nitrogen-containing compounds, especially natural alkaloid derivatives [4]. Since the starting chiral imines are easily accessible in pure enantiomeric form from commercially available materials [5], this methodology has been used successfully for the enantio[6a] and diastereoselective [6b] allylation of imines [7,8]. In this account we will consider non-exhaustively the transition metalcatalyzed reaction of $\mathrm{N}$-sulfinyl imines with different substrates in order to get nitrogen-containing compounds in an enantioselective manner.

\section{Titanium}

Titanium tetraisopropoxide catalyzed the addition of the anion derived from oxindoles $\mathbf{2}$ to $\alpha$-fluorinated imines $\mathbf{1}$ in THF at low temperature. Thus, the corresponding products $\mathbf{3}$ were obtained in good to excellent yields and almost total diastereo- and enan-

\footnotetext{
* Corresponding author.

E-mail address: yus@ua.es (M. Yus).
}

tioselectivities (Scheme 1) [9]. The observed stereochemistry could be explained considering the participation of intermediate $\mathbf{I}$ in the process. Deprotection of one compound $3\left(\mathrm{AcCl}, i \mathrm{PrOH}-\mathrm{EtOH}, 0^{\circ} \mathrm{C}\right)$ allowed the preparation of the corresponding amine in high yield (97\%).

The same starting materials 1 reacted with the lithium reagent derived from 2-alkylpyridines $\mathbf{4}$ in the presence of titanium tetraisopropoxide to yield the expected compounds $\mathbf{5}$ with modest to good yields and high diastereoselectivities (Scheme 2) [10]. Intermediate II has been postulated in order to explain the obtained results. Also in this case one of the products $\mathbf{5}$ was deprotected $(\mathrm{MeOH}$, dioxane, $\mathrm{HCl})$ to afford the corresponding primary amine with excellent yield (98\%).

Butenolides 6 react with sulfinamide $\mathbf{7}$ in the presence of titanium tetraethoxide to give, after reduction with L-Selectride at low temperature, the corresponding protected amino esters 8 (Scheme 3) [11]. Orthogonal deprotection of compounds 8 afforded the expected products in excellent yields. Non-isolated imines III were proposed to be formed and in situ reduced to the final products, and intermediate IV seems to be involved in the process.

Finally, sulfinyl imidates $\mathbf{9}$ reacted with aldehydes $\mathbf{1 0}$ in the presence of $\mathrm{TiCl}_{2}(\mathrm{OiPr})_{2}$ to yield mainly the corresponding antiproducts 11 with both high yields and diastereoselectivities (Scheme 4) [12]. The favored transition state $\mathbf{V}$ has been postulated to explain the observed stereochemistry in this aldol-type process.

\section{Copper}

Imines 1 react with bis(pinacolato)diboron 12 in the presence of $\mathrm{CuSO}_{4}$ and $\mathrm{PCy}_{3} \cdot \mathrm{HBF}_{4}$ to give the corresponding products 13 with 
<smiles>[R]C=NS(=O)C(C)(C)C</smiles>

$\mathrm{R}_{\mathrm{f}}=\mathrm{CF}_{3}, \mathrm{CHF}_{2}$

$R^{1}=$ Boc, Moc, Bn, Me

$\mathrm{R}^{2}=\mathrm{H}, \mathrm{Me}, \mathrm{MeO}, \mathrm{Cl}$

$\mathrm{R}^{3}=\mathrm{H}, \mathrm{Ph}, 4-\mathrm{MeOC}_{6} \mathrm{H}_{4}, 4-\mathrm{ClC}_{6} \mathrm{H}_{4}$<smiles>[R]/C(CC([R])NS(=O)C(C)(C)C)=C1/C(=O)N([Z1])c2ccc([R])cc21</smiles>

3, $55-92 \%$

$84: 6-95: 5 \mathrm{dr}$ 73:27-99:1 Z/E

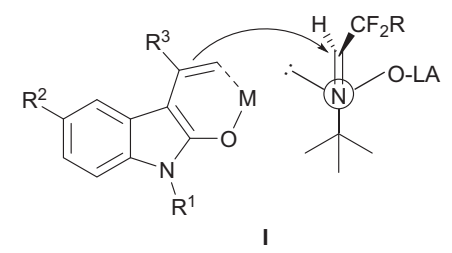

Scheme 1. Preparation of compounds $\mathbf{3}$ from imines $\mathbf{1}$ and oxindoles $\mathbf{2}$.

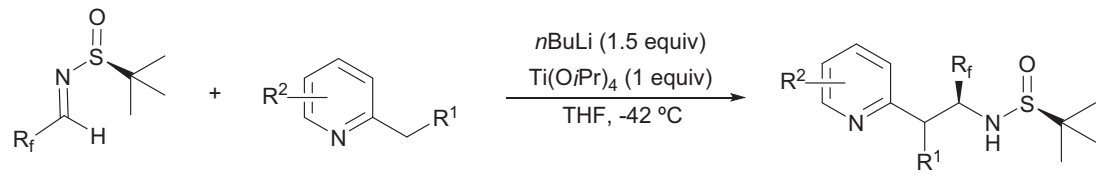

1

4

5, 31-95\%

$80: 20->99: 1 \mathrm{dr}$

$\mathrm{R}_{\mathrm{f}}=\mathrm{CF}_{3}, \mathrm{CHF}_{2}$

$\mathrm{R}^{1}=\mathrm{H}, \mathrm{Me}, \mathrm{CF}_{3}$

$\mathrm{R}^{2}=\mathrm{H}, 6-\mathrm{MeO}, 6-\mathrm{F}, 3-\mathrm{Me}, 4-\mathrm{Me}$, 5,6-benzo

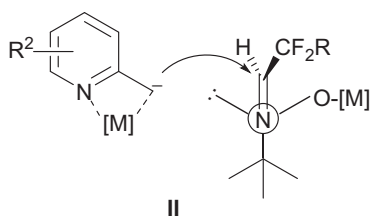

Scheme 2. Preparation of compounds 5 from 1 and 4.

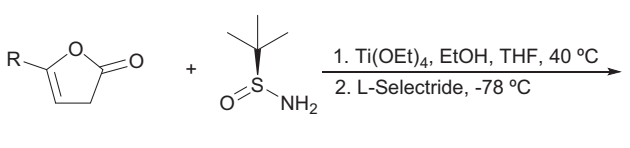

6

$\mathrm{R}=4-\mathrm{MeOC}_{6} \mathrm{H}_{4}, \mathrm{Ph}, 2$-naphthyl, 4-MeC ${ }_{6} \mathrm{H}_{4}$, 3-thienyl, Me<smiles>[R]C(CCC(=O)OCC)=N[S@](=O)C(C)(C)C</smiles>

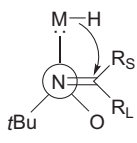

IV

Scheme 3. Preparation of compounds 8 from $\mathbf{6}$ and 7, followed by reduction.

good yields and excellent diastereoselectivities (Scheme 5) [13]. When products 13 were in situ successively treated with $\mathrm{KHF}_{2}$ and $\mathrm{SiO}_{2}-\mathrm{NH}_{4} \mathrm{OH}$ the expected tetrahydroborates 14 were the reac-
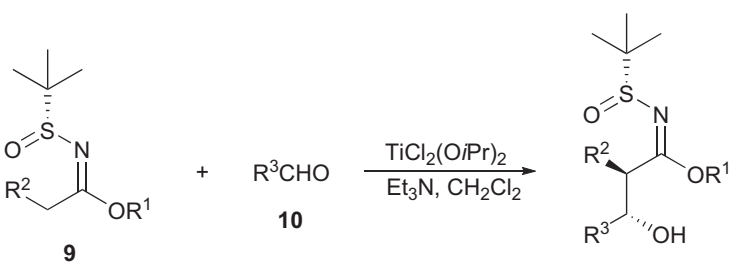

$\mathrm{R}^{1}=\mathrm{Me}, \mathrm{Et}$

$11,84-98 \%$

$\mathrm{R}^{2}=\mathrm{Ph}, \mathrm{Cl}, 4-\mathrm{MeOC}_{6} \mathrm{H}_{4}, 4-\mathrm{FC}_{6} \mathrm{H}_{4}$

$\mathrm{R}^{3}=\mathrm{Ph}, 3-\mathrm{MeOC}_{6} \mathrm{H}_{4}, 4-\mathrm{O}_{2} \mathrm{NC}_{6} \mathrm{H}_{4}, 2-\mathrm{O}_{2} \mathrm{NC}_{6} \mathrm{H}_{4}, 3-\mathrm{BrC}_{6} \mathrm{H}_{4}, 4-\mathrm{BrC}_{6} \mathrm{H}_{4}$, 1-naphthyl, 2-furyl, 2-thienyl, $\mathrm{PhCH}=\mathrm{CH}, t \mathrm{Bu}$

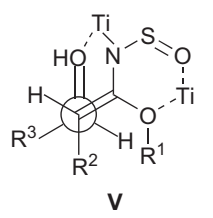

Scheme 4. Preparation of compounds $\mathbf{1 1}$ from $\mathbf{9}$ and $\mathbf{1 0 .}$ 


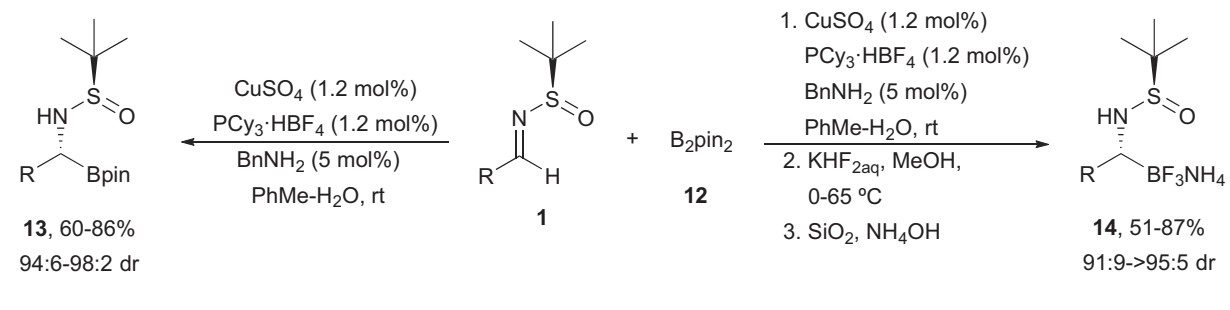

$\mathrm{R}=i \mathrm{Bu}, \mathrm{Cy}, \mathrm{Ph}\left(\mathrm{CH}_{2}\right)_{2}, \mathrm{CbzNH}\left(\mathrm{CH}_{2}\right)_{2}, 4-\mathrm{MeC}_{6} \mathrm{H}_{4}, 2-\mathrm{MeC}_{6} \mathrm{H}_{4}, 4-\mathrm{F}_{3} \mathrm{CC}_{6} \mathrm{H}_{4}, 4-\mathrm{MeOC}_{6} \mathrm{H}_{4}, 4-\mathrm{ClC}_{6} \mathrm{H}_{4}$

Scheme 5. Preparation of compounds 13 and 14 from 1 and 12.

tion products obtained also with good yields and excellent diastereoselectivities. These processes were also applied to a couple of ketimines with similar results.

The CuCl-catalyzed allylation of imines $\mathbf{1}$ with the allylborane $\mathbf{1 5}$ in the presence of the chiral ligand $\mathbf{1 6}$ led to the formation of protected homoallyl amine $\mathbf{1 7}$ with excellent yield and diastereoselectivity (Scheme 6) [14]. The observed stereochemistry was explained considering the transition state VI. On the other hand, the process was also applied to ketimines derived from acetophenones with similar results.

When imines 1 were allowed to react with the diborylmethane 18 under $\mathrm{CuBr}$ catalysis and in the presence of phosphine $\mathbf{1 9}$ the

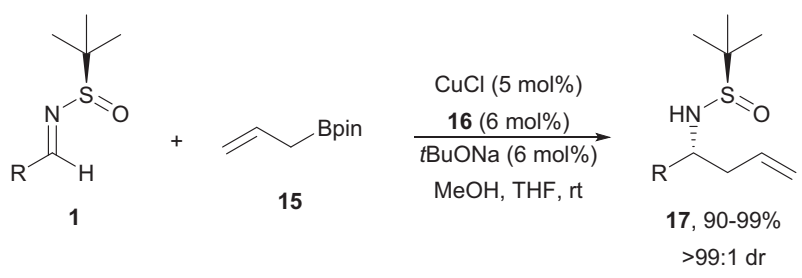

$\mathrm{R}=\mathrm{Ph}, 4-\mathrm{MeC}_{6} \mathrm{H}_{4}, 4-\mathrm{ClC}_{6} \mathrm{H}_{4}, 4-\mathrm{F}_{3} \mathrm{CC}_{6} \mathrm{H}_{4}, 4-\mathrm{MeOC}_{6} \mathrm{H}_{4}, 3-\mathrm{MeC}_{6} \mathrm{H}_{4}, 3-\mathrm{ClC}_{6} \mathrm{H}_{4}$, 2- $\mathrm{MeC}_{6} \mathrm{H}_{4}, 2-\mathrm{ClC}_{6} \mathrm{H}_{4}$, 2-naphthyl, Et, iPr, $\mathrm{Ph}\left(\mathrm{CH}_{2}\right)_{2}$
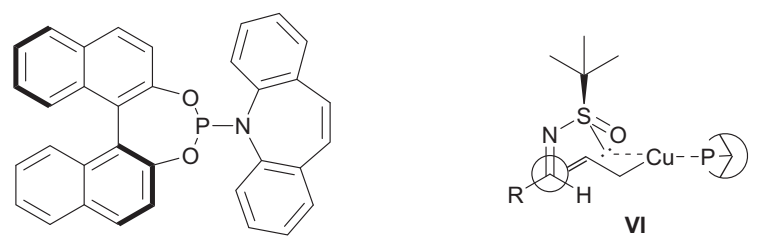

16

Scheme 6. Preparation of compounds 17 from 1 and 15. corresponding products $\mathbf{2 0}$ were obtained, which were oxidized in situ with sodium borate to yield finally protected aminoalcohols 21 (Scheme 7) [15]. Transition state VII can explain the stereochemistry observed in the reaction.

\section{Ruthenium}

The Ru-catalyzed hydrogenation of several $\alpha$-imino esters 22 led mainly to the formation of $\alpha$-amino esters $\mathbf{2 3}$ (Scheme 8) [16]. As the Ru catalyst Ru-MACHO (24) was efficiently used and the corresponding products $\mathbf{2 3}$ were isolated in both excellent yields and diastereoselectivities.

The Ru-catalyzed transfer hydrogenation of ketimines $\mathbf{2 5}$ using isopropanol as hydrogen source and an amino alcohol as ligand under basic conditions afforded the corresponding chiral sulfinyl amines which were in situ deprotected to the corresponding primary amines 26 [17]. As amino alcohol, initially the indanol derivative $\mathbf{2 7}$ was the most efficient as shown in Scheme 9 [18].

An interesting simplification of the above mentioned protocol was the use of the achiral amino alcohol 2-amino-1,1-dimethylethanol as ligand. Under the same reaction conditions, the same amines $\mathbf{2 6}$ were obtained with similar results (Scheme 10) [19].

It is remarkable to underline that the methodology shown in Scheme 10 gives excellent results for aliphatic amines, compared to the procedure described in Scheme 9. Mechanistic calculations (DFT) showed that the reaction involves two transition states and three intermediates, so being a step-wise process and not a concerted one [20]. When the starting material with the opposite configuration was used, the corresponding enantiomeric primary amine was isolated.

A further improvement of the methodology shown in Scheme 10 was the use of microwaves $(40 \mathrm{~W})$ instead of heating: yields and enantioselectivities are similar but the reaction times are significantly reduced (from 1 to $4 \mathrm{~h}$ to less than $30 \mathrm{~min}$ ) [21].

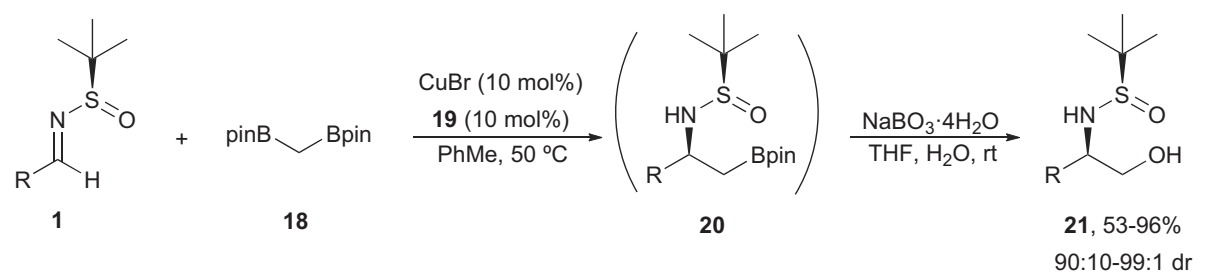

$\mathrm{R}=\mathrm{Ph}, 4-\mathrm{MeC}_{6} \mathrm{H}_{4}, 4-\mathrm{F}_{3} \mathrm{CC}_{6} \mathrm{H}_{4}, 4-\mathrm{ClC}_{6} \mathrm{H}_{4}, 4-\mathrm{BrC}_{6} \mathrm{H}_{4}, 3-\mathrm{MeC}_{6} \mathrm{H}_{4}, 3-\mathrm{ClC}_{6} \mathrm{H}_{4}, 3-\mathrm{BrC}_{6} \mathrm{H}_{4}, 2-\mathrm{MeC}_{6} \mathrm{H}_{4}$, 2-furyl, 2-thienyl<smiles>Pc1cccc(P)c1P</smiles>

19

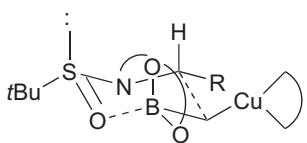

VII

Scheme 7. Preparation of compounds 21 from 1 and $\mathbf{1 8}$ and further oxidation. 
<smiles>[3H]/C(=N/[S@](=O)C(C)(C)C)C(=O)O</smiles>

24 (2 mol\%), $\mathrm{H}_{2} 50$ bar

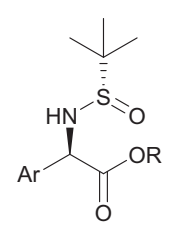

23, $72-97 \%$

$86: 14->99: 1 \mathrm{dr}$

$\mathrm{Ar}=\mathrm{Ph}, 2-\mathrm{MeC}_{6} \mathrm{H}_{4}, 3-\mathrm{MeC}_{6} \mathrm{H}_{4}, 4-\mathrm{MeC}_{6} \mathrm{H}_{4}, 2-\mathrm{MeOC}_{6} \mathrm{H}_{4}, 3-\mathrm{MeOC}_{6} \mathrm{H}_{4}$, 4- $\mathrm{MeOC}_{6} \mathrm{H}_{4}, 2-\mathrm{FC}_{6} \mathrm{H}_{4}, 4-\mathrm{FC}_{6} \mathrm{H}_{4}, 3-\mathrm{ClC}_{6} \mathrm{H}_{4}, 4-\mathrm{ClC}_{6} \mathrm{H}_{4}, 3-\mathrm{BrC}_{6} \mathrm{H}_{4}$, 4- $\mathrm{BrC}_{6} \mathrm{H}_{4}, 3,5-\mathrm{Me}_{2} \mathrm{C}_{6} \mathrm{H}_{3}, 2,4-\mathrm{Me}_{2} \mathrm{C}_{6} \mathrm{H}_{3}, 3,4-\left(\mathrm{OCH}_{2} \mathrm{O}\right) \mathrm{C}_{6} \mathrm{H}_{3}$, 2-naphthyl, 9-phenanthryl

$\mathrm{R}=\mathrm{Me}, \mathrm{Et}, \mathrm{Pr}$

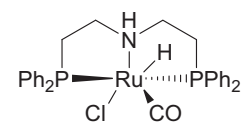

24 (Ru-MACHO)

Scheme 8. Preparation of compound 23 from 22.

1. $\left[\mathrm{RuCl}_{2}(p \text {-cymene })\right]_{2}(5 \mathrm{~mol} \%)$
$27(10 \mathrm{~mol} \%), t \mathrm{BuOK}, i \mathrm{PrOH}$

25

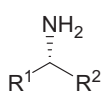

26, $81-99 \%$ $69->99 \%$ ee

$\mathrm{R}^{1}=\mathrm{Cy}, \mathrm{Ph}, 4-\mathrm{BocNHC}_{6} \mathrm{H}_{4}, 3-\mathrm{MeOC}_{6} \mathrm{H}_{4}, 3-\mathrm{ClC}_{6} \mathrm{H}_{4}, 4-\mathrm{ClC}_{6} \mathrm{H}_{4}$, 4- $\mathrm{F}_{3} \mathrm{CC}_{6} \mathrm{H}_{4}, 4-\mathrm{O}_{2} \mathrm{NC}_{6} \mathrm{H}_{4}, 2$-naphthyl, 2-furyl. 2-thienyl

$\mathrm{R}^{2}=\mathrm{Me}, \mathrm{Et}, n \mathrm{Pr}, \mathrm{CH}_{2} \mathrm{Cl},(E)-\mathrm{PhCH}=\mathrm{CH}$<smiles>N[C@H]1c2ccccc2C[C@H]1O</smiles>

27

Scheme 9. Preparation of amines $\mathbf{2 6}$ from imines $\mathbf{2 5}$<smiles>[R]C([R])=NS(=O)C(C)(C)C</smiles>

1. $\left[\mathrm{RuCl}_{2}(p \text {-cymene })\right]_{2}(5 \mathrm{~mol} \%)$

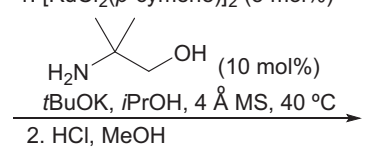

25
$\mathrm{R}^{1} \overbrace{\mathrm{R}^{2}}^{\stackrel{\mathrm{NH}_{3}}{\vdots}}$

26, $71-99 \%$ $65->99 \%$ ee

$\mathrm{R}^{1}=\mathrm{Ph}, 2-\mathrm{MeC}_{6} \mathrm{H}_{4}, 2-\mathrm{MeOC}_{6} \mathrm{H}_{4}, 4-\mathrm{BocNHC}_{6} \mathrm{H}_{4}, 3-\mathrm{MeOC}_{6} \mathrm{H}_{4}, 2-\mathrm{ClC}_{6} \mathrm{H}_{4}$, 3- $\mathrm{ClC}_{6} \mathrm{H}_{4}, 4-\mathrm{ClC}_{6} \mathrm{H}_{4}, 4-\mathrm{F}_{3} \mathrm{CC}_{6} \mathrm{H}_{4}, 4-\mathrm{O}_{2} \mathrm{NC}_{6} \mathrm{H}_{4}, 1$-naphthyl, 2-naphthyl, 2-furyl. 2-thienyl, $\mathrm{Ph}\left(\mathrm{CH}_{2}\right)_{2}, i \mathrm{Pr}, \mathrm{Cy}, t \mathrm{Bu}$

$\left.\mathrm{R}^{2}=\mathrm{Me}, \mathrm{Et}, n \mathrm{Pr}, \mathrm{Pr}, \mathrm{Cy}, \mathrm{E}\right)-\mathrm{PhCH}=\mathrm{CH}$

Scheme 10. Preparation of amines 26 from imines 25.

When the starting imine bears an ester group in one of the $\omega$ positions, such as in $\mathbf{2 8}$, a chiral amino ester was formed that after deprotection spontaneously cyclized to provide enantioenriched substituted lactams 29 (Scheme 11) [22]. In this case, both series of enantiomers were prepared.

The use of $\omega$-chloro imines $\mathbf{3 0}$ allowed the preparation of $\mathrm{N}$-sulfinyl nitrogen-containing heterocycles 31 (Scheme 12) [23]. In this case it was not possible to prepare the starting material with $\mathrm{n}=1$, because a $\beta$-elimination occurred under the reaction conditions assayed. For $n=0,2-4$ the reaction conditions depend on the struc-

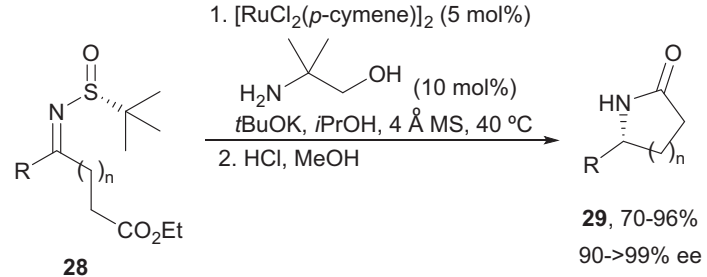

$\mathrm{R}=\mathrm{Ph}, 4-\mathrm{MeOC}_{6} \mathrm{H}_{4}, 4-\mathrm{ClC}_{6} \mathrm{H}_{4}, c \mathrm{C}_{5} \mathrm{H}_{9}, \mathrm{Cy}, i \mathrm{Pr}$, 2-naphthyl, 2-thienyl $\mathrm{n}=1-3$

Scheme 11. Preparation of compounds 29 from 28.

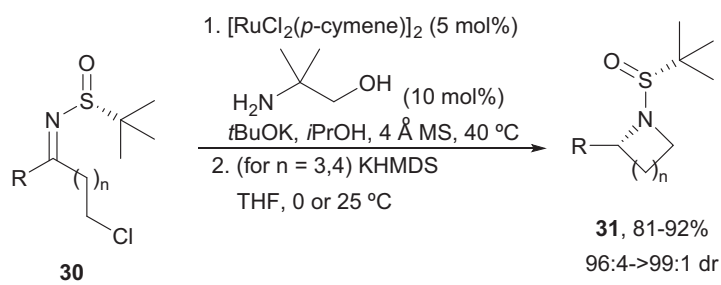

$\mathrm{R}=\mathrm{Ph}, 3-\mathrm{MeC}_{6} \mathrm{H}_{4}, 3-\mathrm{MeOC}_{6} \mathrm{H}_{4}, \mathrm{Me}$

$\mathrm{n}=0,2-4$

Scheme12. Preparation of compounds $\mathbf{3 1}$ from $\mathbf{3 0}$

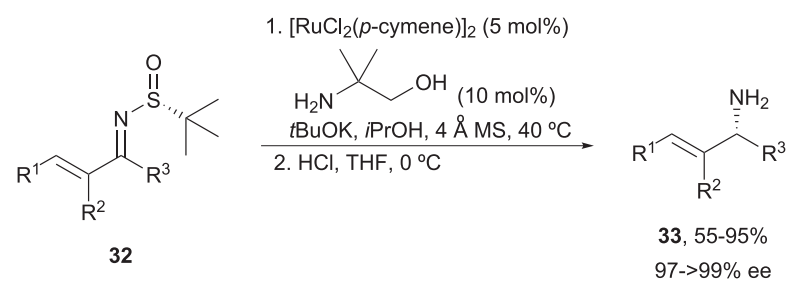

$\mathrm{R}^{1}=\mathrm{Ph}, 4-\mathrm{MeC}_{6} \mathrm{H}_{4}, 4-\mathrm{MeOC}_{6} \mathrm{H}_{4}, 4-\mathrm{ClC}_{6} \mathrm{H}_{4}, 4-\mathrm{O}_{2} \mathrm{NC}_{6} \mathrm{H}_{4}$, 2-naphthyl.

2-furyl, 2-thienyl, 2-pyridyl, 3-pyridyl

$\mathrm{R}^{2}=\mathrm{Me}, \mathrm{Et}, \mathrm{Ph}$

$\mathrm{R}^{3}=\mathrm{Me}, \mathrm{Et}$<smiles>[R]C=C([R])C([R])NS(=O)C1(C)CC1C</smiles>

34 ture of the reaction products: for aziridines and pyrrolidines $(\mathrm{n}=0$, 2 ) the basic conditions medium is sufficient for getting the cyclization. However, for $\mathrm{n}=3,4$ an additional treatment with KHMDS was necessary to promote the cyclization, which in the case of $\mathrm{n}=4$ only worked using the corresponding $\omega$-bromo derivative, instead the chloride.

The same reaction conditions used above have been applied to the synthesis of allyl amines $\mathbf{3 3}$ from $\alpha, \beta$-unsaturated imines $\mathbf{3 2}$ (Scheme 13) [24]. In the case of in situ desulfinylation of $\mathbf{3 4}$ the corresponding primary amines were obtained with good yields and excellent enantioselectivities.

\section{Rhodium}

When perfluorobutane sulfinamide 35 reacted with differently substituted aromatic compounds bearing an ortho-directing group 36 in the presence of a catalytic amount of $\left[\mathrm{Cp}^{*} \mathrm{RhCl}_{2}\right]_{2}$ and $\mathrm{AgB}$ $\left(\mathrm{C}_{6} \mathrm{~F}_{5}\right)_{4}$, the corresponding products 37 were obtained with good 


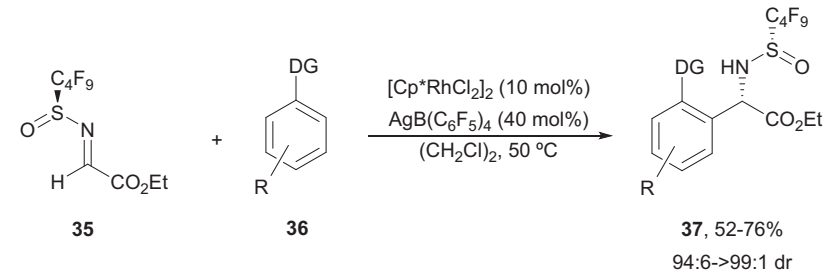

$\mathrm{DG}=\left(\mathrm{CH}_{2}\right)_{4} \mathrm{NCO}, \mathrm{PhN}=\mathrm{N}, 3,5-\mathrm{Me}_{3} \mathrm{C}_{6} \mathrm{H}_{3} \mathrm{~N}=\mathrm{N},\left(\mathrm{CH}_{2}\right)_{4}$ SONCO, 1-pyrazolyl, 4-benzyl-5-triazolyl $\mathrm{R}=\mathrm{H}, 4-\mathrm{Me}, 4-\mathrm{MeO}, 4-\mathrm{Ac}, 5-\mathrm{Me}$

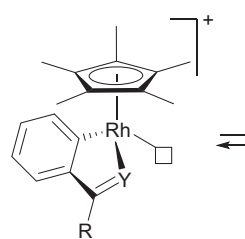

VIII

$\mathrm{Y}=\mathrm{O}, \mathrm{NR}^{\prime}$
+

35

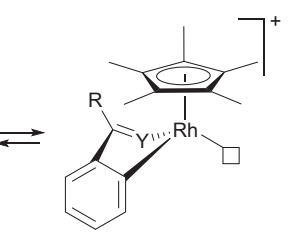

IX

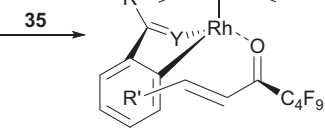

$\mathbf{x}$
$R^{1}, R^{2}, R^{3}, R^{4}=H, M e$

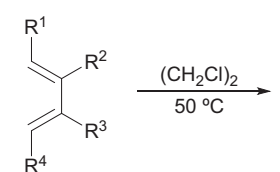

38

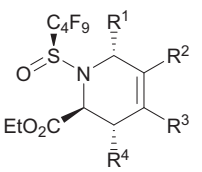

$39,65-81 \%$ $8: 1->98: 2 d r$
Scheme 14. Preparation of compounds 37 and 39 from 35 and 36 or 38 , respectively.

yields and excellent diastereoselectivities (Scheme 14) [25]. A mechanistic study involving intermediates VIII-X has been proposed to explain the obtained stereochemistry. In addition, compounds 35 was assayed as dienophiles in aza-Diels-Alder reactions with different substituted dienes $\mathbf{3 8}$, so the corresponding products 39 were isolated with good yields and high stereoselectivities.
The Rh-catalyzed reaction of several imines $\mathbf{1}$ with sodium tetrafluoroborates $\mathbf{4 0}$ yielded the expected protected amines $\mathbf{4 1}$ with both excellent yields and diastereoselectivities (Scheme 15) [26]. When the starting imine $\mathbf{1}$ contains a chlorine atom at the $\omega$-position the same reaction, followed by in situ treatment with LiHMDS afforded the corresponding pyrrolidines $\mathbf{4 2}$ with similar results.

In the case of imines $\mathbf{4 3}$ derived from cyclic ketones, their Rhcatalyzed reaction with arylboroxine $\mathbf{4 4}$ in the presence of diphosphine 19 led to the corresponding arylated compounds 45 (Scheme 16) [27].

An intramolecular cyclization occurred when compound $\mathbf{4 6}$ were treated with a Rh-catalyst derived from (S)- $\mathrm{H}_{8}$-BINAP (47) giving the corresponding product $\mathbf{4 8}$ as the only reaction adduct (Scheme 17) [28]. Intermediate $\mathbf{X I}$ has been proposed in order to explain the obtained stereochemistry. On the other hand, compounds $\mathbf{4 8}$ were assayed as dienes in Diels-Alder reactions with different dienophiles to afford the expected tricycles with excellent yields.

\section{Palladium}

The reaction of several imines $\mathbf{1}$ with the precursor of trimethylenemethane $\mathbf{4 9}$ in the presence of a catalytic amount of $\mathrm{Pd}\left(\mathrm{PPh}_{3}\right)_{4}$ led to the formation of protected methylidene pyrrolidines $\mathbf{5 0}$ with good yields and diastereoselectivities (Scheme 18) [29]. The reaction was also extended to ketimines, which under the same reaction conditions afforded the corresponding heterocycles with both low yields and diastereoselectivities.

In the case of imines derived from cyclic ketones 51, their allylation with allyl carbonate $\mathbf{5 2}$ in the presence of $\mathrm{Pd}_{2} \mathrm{dba}_{3}$ and $\mathrm{P}$ $(n \mathrm{Bu})_{3}$ allowed the formation of the corresponding $\alpha$-monoallylated compounds $\mathbf{5 3}$ with high yields and diastereoselectivities (Scheme 19) [30]. The same reactions with methallyl or 3-phenylallyl carbonate afforded the corresponding products with similar results.
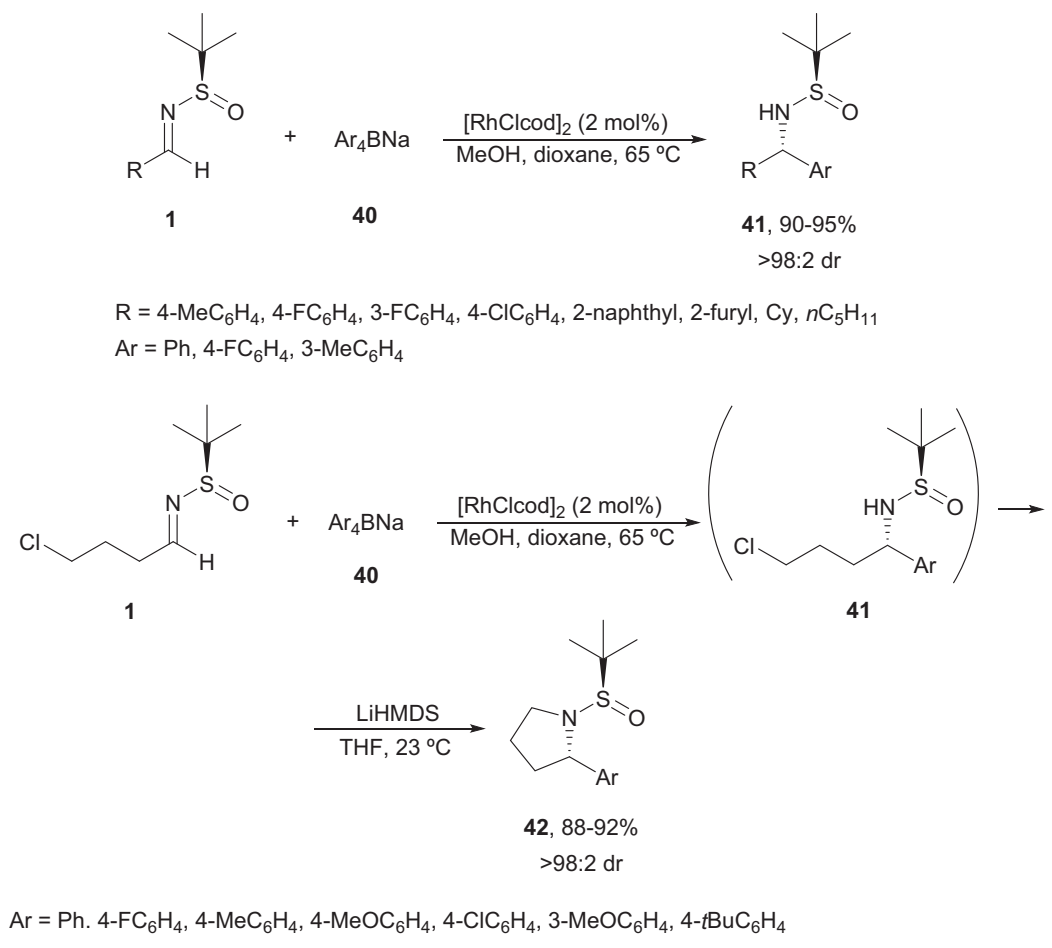

Scheme 15. Preparation of compounds $\mathbf{4 1}$ and $\mathbf{4 2}$ from imines $\mathbf{1}$ and sodium tetraarylborate $\mathbf{4 0 .}$ 
<smiles>CC(C)S(=O)N=C1CC[Y]CC1</smiles>

43

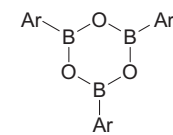

44

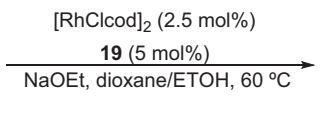

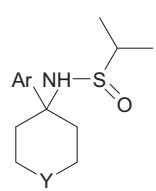

$45,<10-96 \%$
$\mathrm{Y}=\mathrm{CH}_{2}, \mathrm{O}, \mathrm{NBoc}$

$\mathrm{Ar}=\mathrm{Ph}, 4-\mathrm{MeOC}_{6} \mathrm{H}_{4}, 3-\mathrm{MeOC}_{6} \mathrm{H}_{4}, 4-\mathrm{MeC}_{6} \mathrm{H}_{4}, 3-\mathrm{MeC}_{6} \mathrm{H}_{4}, 2-\mathrm{MeC}_{6} \mathrm{H}_{4}, 4-\mathrm{FC}_{6} \mathrm{H}_{4}, 4-\mathrm{ClC}_{6} \mathrm{H}_{4}$,

$3-\mathrm{ClC}_{6} \mathrm{H}_{4}, 4-\mathrm{BrC}_{6} \mathrm{H}_{4}, 4-\mathrm{F}_{3} \mathrm{CC}_{6} \mathrm{H}_{4}, 4-\mathrm{HOCH}_{2} \mathrm{C}_{6} \mathrm{H}_{4}, 4-\mathrm{AcOC}_{6} \mathrm{H}_{4}, 3-\mathrm{AcC}_{6} \mathrm{H}_{4}$

Scheme 16. Preparation of compounds 45 from 43 and 44.
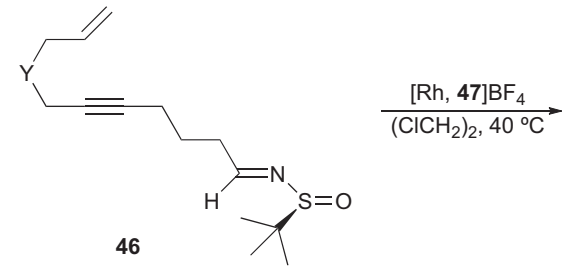

46

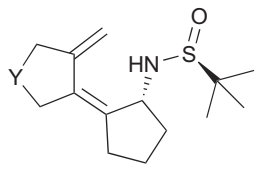

48, $42-83 \%$

$\mathrm{Y}=\left(\mathrm{BnOCH}_{2}\right)_{2} \mathrm{C},\left(\mathrm{AcOCH}_{2}\right)_{2} \mathrm{C}, \mathrm{Me}_{2} \mathrm{C}\left(\mathrm{OCH}_{2}\right)_{2} \mathrm{C}$, 9-fluorenylidene, TsN, NsN

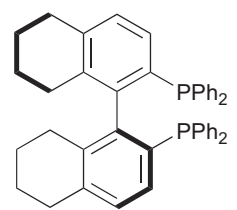

47

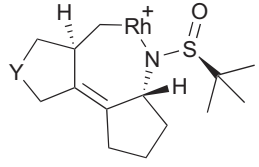

$\mathbf{X I}$
Scheme 17. Preparation of compounds 48 from enynes 46.

\section{Silver}

Silyl dienolates $\mathbf{5 4}$ react with imines $\mathbf{1}$ in the presence of $\mathrm{AgBF}_{4}$ as catalyst to yield homoallyl amines $\mathbf{5 5}$ with excellent yields and diastereoselectivities (Scheme 20) [31]. Curiously, changing the silver salt by TMSOTf the structure of the final products changed

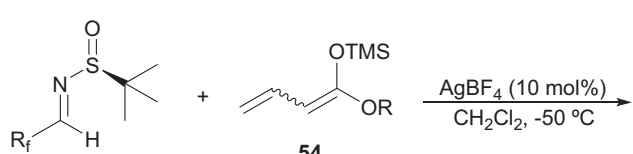<smiles>[R]OC(=O)[C@H](C=C)[C@H]([R])N[SH](=O)C(C)(C)C</smiles>

$\mathrm{R}_{\mathrm{f}}=\mathrm{F}_{3} \mathrm{C}, \mathrm{F}_{2} \mathrm{CH}, \mathrm{F}_{2} \mathrm{BrC}$

$\mathrm{R}=\mathrm{Et}, t \mathrm{Bu}$

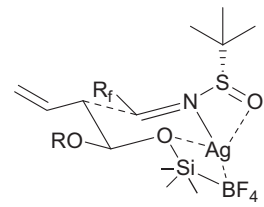

$\mathbf{X I I}$

Scheme 20. Preparation of compounds 55 from 1 and 54

dramatically yielding $\delta$-amino esters. A chelated transition state XII has been postulated to take part in the silver-catalyzed reaction in order to explain the obtained results.

\section{Conclusions}

From the results contained in this account we conclude that transition metal-catalyzed reactions of chiral aldimines and ketimines with different substrates represent a new way to prepare chiral amine derivatives, this methodology being complementary to that one using organometallic compounds derived from main group metals. Titanium, copper, ruthenium, rhodium, palladium and silver have been successfully used to catalyze several processes involving the addition to the $\mathrm{C}=\mathrm{N}$ bond or the reaction at the $\alpha$-position with respect to this bond. Some synthetic applications of these methodologies have been included in this short review.

\section{Declaration of Competing Interest}

The authors declare that they have no known competing financial interests or personal relationships that could have appeared to influence the work reported in this paper.

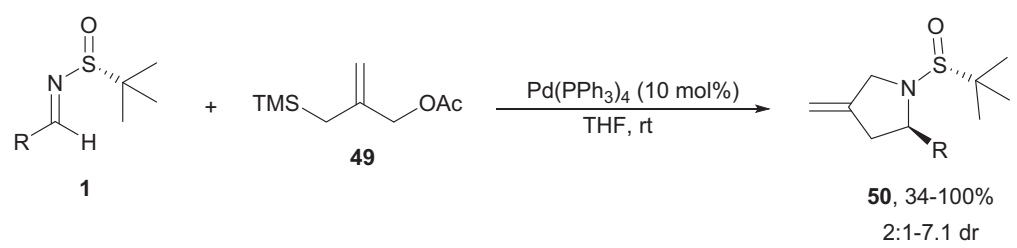

$\mathrm{R}=\mathrm{Ph}, 4-\mathrm{MeOC}_{6} \mathrm{H}_{4}, 4-\mathrm{O}_{2} \mathrm{NC}_{6} \mathrm{H}_{4}, 2-\mathrm{HOC}_{6} \mathrm{H}_{4}, 2-\mathrm{ClC}_{6} \mathrm{H}_{4}, 2-\mathrm{BrC}_{6} \mathrm{H}_{4}, \mathrm{Cy}$, tBu, 2-furyl, 2-thienyl, 2-naphthyl

Scheme 18. Preparation of compounds 50 from 1 and 49.

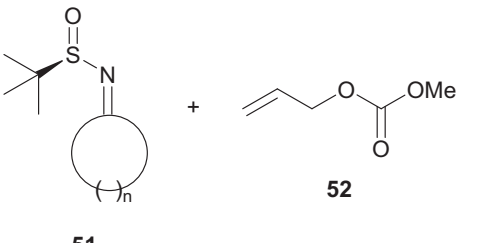

51

$n=3,5-7,11$

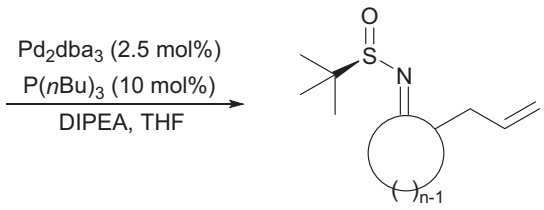

53, 64-94\% $14: 1->25: 1 \mathrm{dr}$

Scheme 19. Preparation of compounds 53 from 51 and 52. 


\section{Acknowledgements}

We thank the continuous financial support from the Spanish Ministerio de Economía y Competitividad (MINECO; project CTQ2016-81797-REDC, CTQ2017-85093-P), Ministerio de Ciencia, Innovación y Universidades (RED2018-102387-T, PID2019-107268 GB-100), FEDER, the Generalitat Valenciana (PROMETEOII/2014/017), and the University of Alicante (VIGROB-068).

\section{References}

[1] J. Ramirez Hernandez, F. Chemla, F. Ferreira, O. Jackowski, J. Oble, A. PerezLuna, G. Poli, Chimia 70 (2016) 84.

[2] F. Foubelo, M. Yus, Chem. Rec. (2020), https://doi.org/10.1002/tcr.202000122.

[3] F. Foubelo, M. Yus, Eur J. Org. Chem. (2014) 485

[4] F. Foubelo, M. Yus, Chem. Today 34 (2016) 45.

[5] (a) G. Liu, D.A. Cogan, T.D. Owens, T.P. Tang, J.A. Ellman, J. Org. Chem. 64 (1999) 1278;

(b) J.F. Collados, E. Toledano, D. Guijarro, M. Yus, J. Org. Chem. 77 (2012) 5744;

(c) For the use of $N$-p-tolylsulfinyl imines, see for instance:F.A. Davis, P. Xu, J. Org. Chem. 76 (2011) 3329.

[6] (a) M. Yus, J.C. González-Gómez, F. Foubelo, Chem. Rev. 111 (2011) 7774;

(b) M. Yus, J.C. González-Gómez, F. Foubelo, Chem. Rev. 113 (2013) 5595.

[7] (a) J.C. González-Gómez, F. Foubelo, M. Yus, Org. Synth. 89 (2012) 88; (b) M. Yus, Org. Synth. 96 (2019) 179.

[8] (a) A. Lahosa, F. Foubelo, M. Yus, Eur. J. Org. Chem. (2016) 4067;

(b) E. Maciá, F. Foubelo, M. Yus, Tetrahedron 72 (2016) 6001;

(c) M.J. García-Muñoz, F. Foubelo, M. Yus, J. Org. Chem. 81 (2016) 10214;

(d) A. Sirvent, T. Soler, F. Foubelo, M. Yus, Chem. Commun. 53 (2017) 2701;

(e) E. Maciá, F. Foubelo, Yus M. Tetrahedron: Asymmetry 28 (2017) 1407;

(f) S. Ikhlef, C. Behloul, A. Lahosa, F. Foubelo, M. Yus, Eur. J. Org. Chem. (2018) 2609;

(g) M.J. García-Muñoz, A. Sirvent, F. Foubelo, M. Yus, An. Acad. Bras. Cienc. 90 (2018) 1059;

(h) M. Benlahrech, A. Lahosa, C. Behloul, F. Foubelo, M. Yus, Heterocycles 97 (2018) 1191; (i) J.A. Mendes, P. Merino, T. Soler, E.J. Salustiano, P.R.R. Costa, M. Yus, F. Foubelo, C.D. Buarque, J. Org. Chem. 84 (2019) 2219;

(j) A. Lahosa, M. Yus, F. Foubelo, J. Org. Chem. 84 (2019) 7331;

(k) E. Maciá, F. Foubelo, M. Yus, Heterocycles 99 (2019) 248;

(1) S. Hernández-Ibáñez, O. Soares do Rego Barros, A. Lahosa, M.J. GarcíaMuñoz, M. Benlahrech, C. Behloul, F. Foubelo, M. Yus, Tetrahedron 76 (2020) 130842.

[9] Y. Liu, Y. Yang, Y. Huang, X.-H. Xu, F.-L. Qing, Synlett 26 (2015) 67.

[10] J. Yang, J. Zhang, W. Meng, Y. Huang, Tetrahedron Lett. 56 (2015) 6556.

[11] L.R. Reddy, K. Prasad, M. Prahsad, J. Org. Chem. 77 (2012) 6296.

[12] H.E. Bartrum, A. Viceriat, S. Carret, J.-F. Poisson, Org. Lett. 16 (2014) 1972.

[13] A.W. Buesking, V. Bacaunanu, I. Cai, J.A. Ellman, J. Org. Chem. 79 (2014) 3671.

[14] Y.-S. Zhao, Q. Liu, P. Tian, J.-C. Tao, Org. Biomol. Chem. 13 (2015) 4174.

[15] J. Park, Y. Lee, J. Kim, S.H. Cho, Org. Lett. 18 (2016) 1210.

[16] Q. Wei, F. Zhang, X. Zhao, C. Wang, J. Xiao, W. Tang, Org. Biomol. Chem. 15 (2017) 5468

[17] (a) D. Guijarro, O. Pablo, M. Yus, Org. Synth. 90 (2013) 338;

(b) M. Yus, Org. Synth. 96 (2019) 232.

[18] (a) D. Guijarro, O. Pablo, M. Yus, Tetrahedron Lett. 50 (2009) 5386; (b) D. Guijarro, O. Pablo, M. Yus, J. Org. Chem. 75 (2010) 5265.

[19] D. Guijarro, O. Pablo, M. Yus, Tetrahedron Lett. 52 (2011) 789.

[20] O. Pablo, D. Guijarro, G. Kovács, A. Lledós, G. Ujaque, M. Yus, Chem. Eur. J. 18 (2012) 1969.

[21] O. Pablo, D. Guijarro, M. Yus, Eur. J. Org. Chem. (2014) 7034.

[22] D. Guijarro, O. Pablo, M. Yus, J. Org. Chem. 78 (2013) 3647.

[23] O. Pablo, D. Guijarro, M. Yus, J. Org. Chem. 78 (2013) 9181.

[24] E. Selva, Y. Sempere, D. Ruiz-Martínez, O. Pablo, D. Guijarro, J. Org. Chem. 82 (2017) 13693.

[25] (a) A. Wangweerawong, R.G. Bergman, J.A. Ellman, J. Am. Chem. Soc. 136 (2014) 8520;

(b) A. Wangweerawong, J.R. Hummel, R.G. Bergman, J.A. Ellman, J. Org. Chem. 81 (2016) 1547.

[26] L.R. Reddy, A.P. Gupta, E. Villhauer, Y. Liu, J. Org. Chem. 77 (2012) 1095.

[27] H.H. Jung, A.W. Buesking, J.A. Ellman, J. Org. Chem. 77 (2012) 9593.

[28] Y. Oonishi, Y. Hato, Y. Sato, Adv. Syhth. Catal. 358 (2016) 2273.

[29] G. Procopiou, W. Lewis, G. Harbottle, R.A. Stockman, Org. Lett. 15 (2013) 2030.

[30] J. Li, R.S. Dawood, S. Qin, T. Liu, S. Liu, R.A. Stockman, S. Jiang, G. Yang, Tetrahedron Lett. 58 (2017) 1146.

[31] Y. Liu, J. Liu, Y. Huang, F.-L. Qing, Chem. Commun. 49 (2013) 7492. 